\title{
EGALITARIAN AWARENESS IN THE CAPITALISTIC REALITY. THE ENTANGLEMENT OF POVERTY AND WEALTH IN DAILY SOCIAL SPHERE 25 YEARS AFTER THE SYSTEM CHANGE IN POLAND
}

The purpose of the article is to illustrate the social order preferred by the Polish together with their assessment of the existing social inequalities. On the basis of the empirical material collected among the sample of 1000 respondents, the findings show manners of their definition of equity, perception of discrepancies between the ideal of equity and the existing real status, together with their assessment of the existing differences in the treatment of rich and poor people by various institutions (banks, police, hospitals, courts). The article also describes the causes of social inequalities as indicated by the respondents and their assessment of state policies in reference to them. The article concludes that 25 years after the collapse of "real socialism", Polish society presents a firmly egalitarian awareness that is in conflict with the current market order.

Keywords: social inequalities, the state, system transformations, transformation of the Polish society.

doi:10.2478/sho-2014-0001

The 25 years which have passed since the political changes in Central and Eastern Europe is a good time for a reflection upon the manner of structural changes taking place in the social and economical sphere have influenced the social awareness of citizens of the region. The empirical data gathered in 2013 will be used for our considerations.

It is worth recalling that the democratic opposition of the 1980s in Poland did not take into consideration the restoration of capitalistic relations in the social and economical sphere. The programme of the first "Solidarity" congress under the name of "Self-governing Republic" called for far-reaching staff self-government at work places. As noted by Jerzy Szacki, "circles of the democratic opposition got fed by an idea of a 'third way' leading to a society which is both post-communist and post- 
capitalist"1. Independence and "living in truth" were to be conditioned by a sort of a vague sphere beyond the control of the state and the market. The leaders of the democratic opposition assumed that "it is possible to create an autonomous social sphere - civil society which in factual (not only analytical) terms can be separated both from a political society and an economic society" 2 .

These general assumptions together with substantial demands postulated during social strikes and protests in the 1980s formed a vision of a very egalitarian society or even "socialism without distortions and with its human face". Then the market transformations which were launched in Poland at the beginning of the 90s upon the fall of the "Eastern Block" had to be even more pronounced in people's minds.

Referring to the concept made by Marshall who considered that full citizenship is composed of three types of rights (civil, political and social), it can be concluded that the system breakthrough has certainly strengthened civil and political rights of citizens in Poland, but it has firmly undermined social rights. T. H. Marshall outlined the chronology of evolution of civil rights in Europe and found that three types of civil rights can be attributed to three subsequent centuries: civil rights - to the eighteenth century, political rights - to the nineteenth century, social rights - to the twentieth century ${ }^{3}$. Along the same line of thinking, it should be concluded that the twentieth first century will either stand for a transfer of these three types of rights at the transnational level and their reinforcement or these former rights confined within the national boundaries will lose their power at the age of global capitalism. Social rights will suffer most in the second case. And together with them, political and civil rights will be a threat as well.

Unfortunately, this process can be observed in Eastern Europe where the limitation of social security as a result of the restoration of capitalism in its neo-liberal version in the 90s has produced disappointment among its citizens, discouragement towards politics, lack of engagement in the public sphere and an overall threat to the observance of political rights.

Interestingly, 25 years of neoliberal policies in this part of the world did not bury the egalitarian consciousness settled during the period of "real socialism". The empirical data presented in this article shows that Polish

\footnotetext{
${ }^{1}$ J. Szacki, Liberalizm po komunizmie, Kraków 1994, pp. 92-93.

2 Ibidem, pp.125-126.

3 See R. Dahrendorf, Nowoczesny konflikt społeczny, Warszawa 1993, pp.72-73.
} 
Chart 1. Comprehension of equality

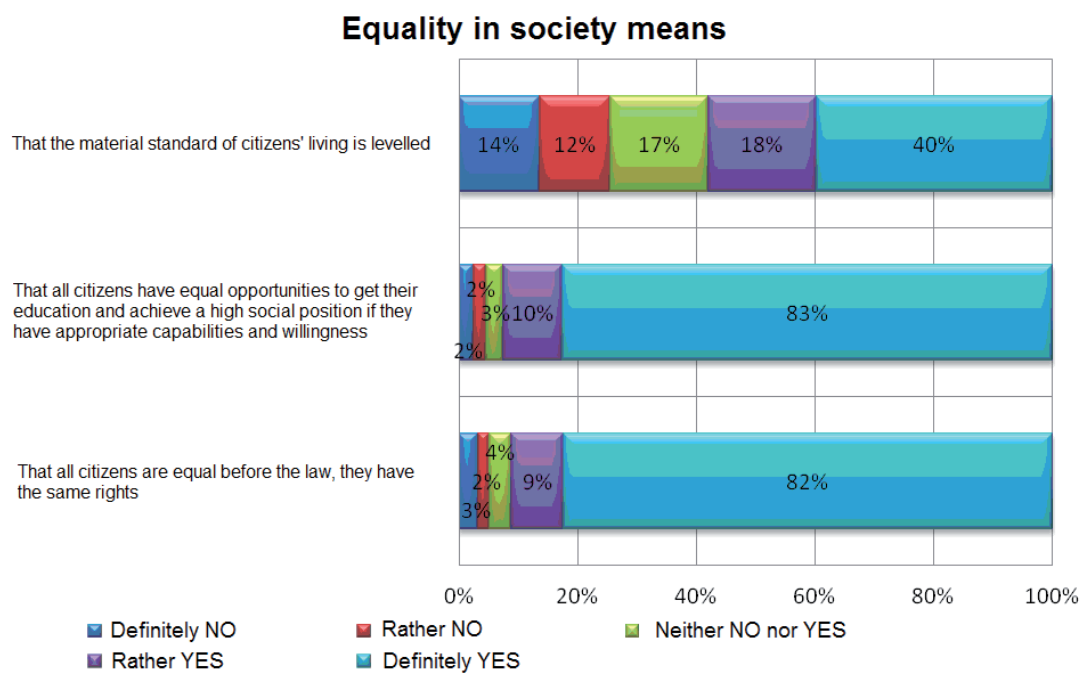

Source: Centrum Monitoringu Spotecznego

citizens - at the level of their own conceptions of a "good society" - still remain very egalitarian in their desires and longings for better order ${ }^{4}$.

As shown in Figure 1, equal rights (91\%) and equal opportunities to acquire education $(93 \%)$ are treated by an overwhelming majority of the respondents as an element which defines equality in society. But still up to $58 \%$ of the respondents consider "an equal material standard of life among citizens" as a significant feature of an egalitarian society.

These conceptions of equality differ completely from the assessment of equal opportunities in Polish reality. Up to $78 \%$ of the respondents rejected a statement that "all citizens are guaranteed a decent standard of living". Also, a high percentage of them do not agree with the opinion that "all have equal opportunities, regardless of their material situation" (74\%) and with the assertion that "all have equal opportunities, regardless of material situation" (67\%).

These results demonstrate the total mismatch of these conceptions on equity with the Polish social practice 25 years after the change of the system. They are also a sign of rejection of the current state policies and a longing for at least a social-oriented state, or even directly for a socialist county.

4 The collected empirical data come from 2013 and - though the surveys were performed within the region of Lower Silesia (the south-western part of Poland), the general trends outlined in these surveys are valid for the whole of Polish society. 
Chart 2. Opinions of the respondents about equal opportunities in Poland. N=1000

In Poland:

All citizens are guaranteed a decent standard of living

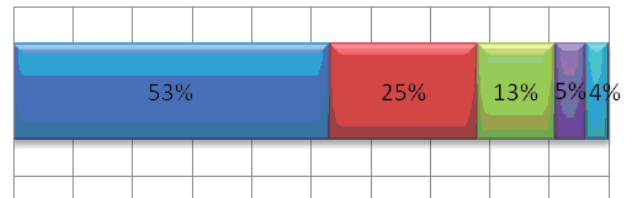

All have equal opportunities regardless of their material standing

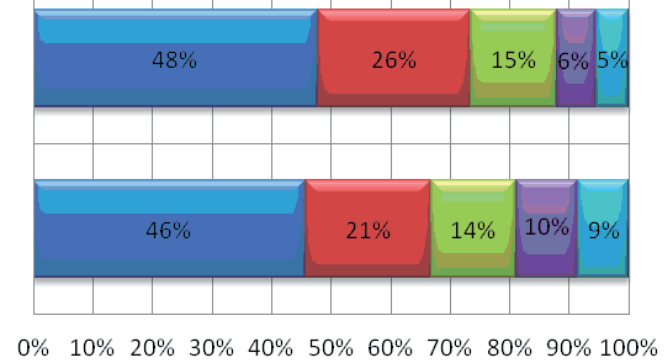

All have equal opportunities regardless of their social origin

$\square$ Definitely NO $\square$ Rather NO $\square$ Neither NO or YES $\square$ Rather YES $\square$ Definitely YES

Source: Centrum Monitoringu Społecznego

\section{THE STATE AND SOCIAL DISPARITIES}

A question on policies run by the state comes down to an issue of functions fulfilled by the state. The changes taking place in the 90s in Poland meant a departure from repressive and police-based functions of the state, limitation of the state and its share in the economic sphere and bringing the state to play the role of a night watchman who is to provide basic security needs only. It was consistent with the principles of neo-liberalism which since the beginning of the 90s have become the binding doctrine in Poland and within this part of the world. According to Milton Friedman, a capitalistic system is fully capable of developing without state intervention. State intervention - in Friedman's opinion - was not only unnecessary but also harmful. This statement forms the grounds for a postulate - one of the main dogmas of the neo-liberals - on "limiting the role or function of the state in the economic sphere while concentrating on defence, protection of the basic institutions of private entrepreneurship and freedom of operation of the market mechanism" ${ }^{\prime 5}$. In such conditions, the state is released

\footnotetext{
${ }^{5}$ S. Zawadzki, Państwo o orientacji społecznej, Warszawa 1996, p. 99.
} 
from any liability for social security of its citizens, their employment or provision of access to efficient public services. All problematic issues are to be resolved by the market and free competition within it. Inequalities in such conditions become a permanent and integral element of the soconstructed social order. The state is only required to ensure freedom and ease for doing business by market actors.

As Zygmunt Bauman says, "global finance, commerce and industry based on information due to freedom of movement and unfettered ease at their aspiration to achieve their own objectives are subject to political fragmentation, disintegration of the global political scene. It can be said that all of them are interested in the existence of weak countries or - in other words - weak organisms which still remain countries" ${ }^{\prime 6}$. Without a minimum of safety and peace of mind, it is not possible to earn money and grow economically. Therefore, "weak quasi-countries can be easily brought down to their useful function of police districts, providing a bit of order needed to do business; however, one should not worry whether or not they can effectively restrict the operational freedom of companies and enterprises" 7 .

The public have actually interpreted such policies in this manner. Therefore, it should not be any surprise that nearly $54 \%$ of the respondents consider that the Polish state mostly protects the interests of high-income people. According to about $6 \%$ of them, the state stands on the side of middle-income people and only $34 \%$ of the respondents declare that the state remains neutral and does not stand at anybody's side. A distribution of the respondents' responses on their occupied positions in the social structure and performed occupation is of interest. Both private entrepreneurs $(42,9 \%)$ together with pupils and students (54,5\%) most often believe that the state does not stand at anybody's side. However, unemployed people $(61,9 \%)$, disability pensioners $(62,1 \%)$ and public-sector employees $(58,9 \%)$ most often believe that the state protects the interests of high-income earners.

Religiosity is another variable which affects the assessment of the state and its approach to citizens. It turns out that $63,3 \%$ of the most religious people declare that the state stands at the side of the wealthy. $51,5 \%$ of people who do not participate in religious services declared so. The variance, therefore, is equal to about $12 \%$. A similar spread was between the

\footnotetext{
${ }^{6}$ Z. Bauman, Globalizacja, Warszawa 2000, p. 82.

${ }^{7}$ Ibidem.
} 
same categories of the respondents in their opinions on class neutrality of the state. $23,3 \%$ of people who attend religious services several times a week declare that the state does not stand at anybody's side. More than $36 \%$ of people who do not attend religious services declared so.

It is worth noting that political views declared by the respondents do not indicate a particular assessment of state policies. This is a whole subject unto itself, but briefly it can be said that political views in Poland are created on the grounds of identity divisions rather than on class divisions. Culture is more important than class related to individual interests and position within the social structure. The residents who defined themselves as "centrists" were the only distinguishing category among all the political variables. Most often they declare that the state is neutral $(46,4 \%)$ and least often among all other groups $(39,1 \%)$, they agree with the thesis that the state protects the interests of the elite. Supporters of economic liberalism probably acted under slogans of "centrist" views.

And what are social expectations in terms of the role fulfilled by the state? Most people would like the state to be a neutral arbitrator which reconciles conflicting interests of particular social categories - it was declared so by nearly $62 \%$ of the respondents. At the same time every fourth respondent declares that the state should stand at the side of low-income people and about $14 \%$ consider that it should protect "middle-income people". Only traces of the respondents $(0,2 \%)$ considered that the state should stand at the side of high-income earners.

Farmers, disability and old-age pensioners most often indicated that the state should protect low-income people. Another factor affecting the respondents' opinions refers to their age. The dependency is simple: the older the people are, the more prone they are to place the state in the role of defender of the poor.

In general, however, the respondents' opinions indicate a convergence of their expectations with the objectives of the social-oriented state which, according to Sylwester Zawadzki, runs active social policies covering among others: social support for poor and disadvantaged people, providing people with equal opportunities in their pursuit for social advancement through the development of education, effective mitigation of social conflicts and reduction of disparities in the distribution of national income between high- and low-income persons ${ }^{8}$.

${ }^{8}$ S. Zawadzki, Państwo o orientacji społecznej, op. cit. p. 178. 
Table 1.

In your opinion does the state protect the interests of:

\begin{tabular}{|c|c|c|c|c|c|}
\hline & $\begin{array}{l}\text { High- } \\
\text { income } \\
\text { people }\end{array}$ & $\begin{array}{l}\text { Middle- } \\
\text { income } \\
\text { people }\end{array}$ & $\begin{array}{l}\text { Low- } \\
\text { income } \\
\text { people }\end{array}$ & $\begin{array}{l}\text { It does not } \\
\text { stand at } \\
\text { anybody's } \\
\text { side }\end{array}$ & $\begin{array}{l}\text { It is diffi- } \\
\text { cult to say }\end{array}$ \\
\hline & \multicolumn{5}{|c|}{$\%$} \\
\hline Total & 53,7 & 5,9 & 2,6 & 33,7 & 4,1 \\
\hline \multicolumn{6}{|c|}{ Sex } \\
\hline Men & 56,8 & 5,3 & 1,5 & 32,8 & 3,6 \\
\hline Women & 50,9 & 6,5 & 3,6 & 34,5 & 4,6 \\
\hline \multicolumn{6}{|c|}{ Age } \\
\hline $18-24$ & 55,6 & 5,6 & 3,7 & 34,3 & 0,9 \\
\hline $25-34$ & 53,5 & 4,5 & 4,0 & 36,1 & 2,0 \\
\hline $35-44$ & 51,8 & 5,9 & 0,6 & 37,1 & 4,7 \\
\hline $45-54$ & 63,5 & 7,1 & 1,3 & 24,4 & 3,8 \\
\hline $55-64$ & 55,2 & 5,7 & 2,6 & 32,8 & 3,6 \\
\hline 65 and over & 43,4 & 7,5 & 4,0 & 36,4 & 8,7 \\
\hline \multicolumn{6}{|c|}{ Political opinions } \\
\hline Left-wing & 57,0 & 5,0 & 3,0 & 33,0 & 2,0 \\
\hline Rather left-wing & 47,5 & 8,9 & 5,9 & 31,7 & 5,9 \\
\hline Central-wing & 39,1 & 5,1 & 3,6 & 46,4 & 5,8 \\
\hline Rather right-wing & 51,7 & 4,3 & 1,7 & 40,5 & 1,7 \\
\hline Right-wing & 58,5 & 6,3 & 2,8 & 29,6 & 2,8 \\
\hline It is difficult to say & 57,5 & 5,9 & 1,7 & 29,6 & 5,2 \\
\hline \multicolumn{6}{|c|}{ Religious services } \\
\hline A few times a week & 63,3 & 6,7 & 3,3 & 23,3 & 3,3 \\
\hline Once a week & 52,6 & 6,8 & 3,5 & 32,6 & 4,4 \\
\hline A few times a month & 57,0 & 6,1 & 4,4 & 28,9 & 3,5 \\
\hline A few times a year & 53,5 & 4,2 & 1,4 & 37,0 & 3,9 \\
\hline I do not attend at all & 51,4 & 6,5 & 2,2 & 36,2 & 3,8 \\
\hline \multicolumn{6}{|c|}{ Professional standing } \\
\hline Public sector staff & 58,9 & 4,5 & 1,8 & 32,1 & 2,7 \\
\hline Private sector staff & 55,0 & 6,4 & 1,9 & 33,2 & 3,5 \\
\hline Private entrepreneurs & 47,6 & 4,8 & 0,0 & 42,9 & 4,8 \\
\hline Farmers & 56,2 & 6,2 & 6,2 & 31,2 & 0,0 \\
\hline Disability pensioners & 62,1 & 0,0 & 0,0 & 34,5 & 3,4 \\
\hline Old-age pensioners & 46,1 & 8,6 & 3,7 & 34,3 & 7,3 \\
\hline Pupils and students & 38,6 & 0,0 & 4,5 & 54,5 & 2,3 \\
\hline Unemployed persons & 61,9 & 7,1 & 4,8 & 23,8 & 2,4 \\
\hline $\begin{array}{l}\text { Other economically in- } \\
\text { active }\end{array}$ & 57,5 & 5,0 & 7,5 & 27,5 & 2,5 \\
\hline
\end{tabular}

Source: Centrum Monitoringu Społecznego 
Table 2.

\begin{tabular}{|c|c|c|c|c|c|}
\hline \multicolumn{6}{|c|}{ In your opinion, should the state stand at the side of } \\
\hline & $\begin{array}{l}\text { High- } \\
\text { income } \\
\text { people }\end{array}$ & $\begin{array}{l}\text { Middle- } \\
\text { income } \\
\text { people }\end{array}$ & $\begin{array}{l}\text { Low- } \\
\text { income } \\
\text { people }\end{array}$ & $\begin{array}{l}\text { It should } \\
\text { stand at } \\
\text { nobody's } \\
\text { side }\end{array}$ & $\begin{array}{l}\text { It is diffi- } \\
\text { cult to say }\end{array}$ \\
\hline & \multicolumn{5}{|c|}{$\%$} \\
\hline Total & 0,2 & 13,6 & 22,2 & 61,7 & 2,3 \\
\hline \multicolumn{6}{|c|}{ Sex } \\
\hline Men & 0,2 & 10,8 & 20,7 & 66,4 & 1,9 \\
\hline Women & 0,2 & 16,1 & 23,5 & 57,5 & 2,7 \\
\hline \multicolumn{6}{|c|}{ Age } \\
\hline $18-24$ & 0,0 & 8,3 & 13,0 & 76,9 & 1,9 \\
\hline $25-34$ & 0,0 & 9,0 & 19,9 & 69,2 & 2,0 \\
\hline $35-44$ & 0,0 & 16,4 & 18,7 & 61,4 & 3,5 \\
\hline $45-54$ & 0,6 & 12,9 & 24,5 & 60,6 & 1,3 \\
\hline $55-64$ & 0,0 & 15,7 & 26,2 & 55,5 & 2,6 \\
\hline 65 and over & 0,6 & 17,8 & 27,6 & 51,7 & 2,3 \\
\hline \multicolumn{6}{|c|}{ Political opinions } \\
\hline Left-wing & 0,0 & 15,2 & 17,2 & 65,7 & 2,0 \\
\hline Rather left-wing & 1,0 & 12,0 & 19,0 & 67,0 & 1,0 \\
\hline Central-wing & 0,0 & 12,3 & 21,0 & 64,5 & 2,2 \\
\hline Rather right-wing & 0,0 & 8,6 & 19,0 & 72,4 & 0,0 \\
\hline Right-wing & 0,0 & 14,2 & 20,6 & 63,8 & 1,4 \\
\hline It is difficult to say & 0,2 & 15,5 & 25,9 & 54,7 & 3,7 \\
\hline \multicolumn{6}{|c|}{ Religious services } \\
\hline A few times a week & 0,0 & 11,5 & 29,5 & 59,0 & 0,0 \\
\hline Once a week & 0,0 & 15,6 & 25,0 & 57,6 & 1,8 \\
\hline A few times a month & 0,0 & 14,9 & 24,6 & 59,6 & 0,9 \\
\hline A few times a year & 0,7 & 13,4 & 20,8 & 62,0 & 3,2 \\
\hline I do not attend at all & 0,0 & 10,3 & 15,2 & 72,3 & 2,2 \\
\hline Refused to answer & 0,0 & 16,7 & 22,2 & 44,4 & 16,7 \\
\hline \multicolumn{6}{|c|}{ Professional standing } \\
\hline Public sector staff & 0,0 & 14,7 & 17,0 & 66,1 & 2,2 \\
\hline Private sector staff & 0,3 & 11,2 & 21,5 & 64,4 & 2,6 \\
\hline Private entrepreneurs & 0,0 & 16,3 & 14,0 & 69,8 & 0,0 \\
\hline Farmers & 0,0 & 18,8 & 31,2 & 50,0 & 0,0 \\
\hline Disability pensioners & 0,0 & 10,3 & 37,9 & 51,7 & 0,0 \\
\hline Old-age pensioners & 0,4 & 17,1 & 28,6 & 51,8 & 2,0 \\
\hline Pupils and students & 0,0 & 6,7 & 13,3 & 77,8 & 2,2 \\
\hline Unemployed persons & 0,0 & 9,5 & 19,0 & 64,3 & 7,1 \\
\hline $\begin{array}{l}\text { Other economically in- } \\
\text { active }\end{array}$ & 0,0 & 15,4 & 25,6 & 59,0 & 0,0 \\
\hline
\end{tabular}




\section{SOCIAL INEQUALITIES AND SOCIAL PRACTICE}

Grzegorz Kołodko acknowledges that at the time of the system transformation in Poland, "its significant income stratification negatively affected its economic growth. For some time it has been reflected by the resurging Gini coefficient and increasing spread between extreme income deciles. While trying to build a social market economy, even in the mid90 s, the escalating economic stratification of our society was successfully managed to be held back; however at the period of the dominance of neo-liberal doctrine, the increase of labour productivity was not paid with equivalent increases in real wages" ${ }^{\prime \prime}$. The process is even more noticeable in specific situations in our public life. The respondents have got no doubts that a different class situation affects different treatment in various institutions of our collective life.

In Poland health care is the sphere of public life which reveals these inequalities most clearly. At the same time it is the most commercialised sector of our collective life. On one hand commercialisation stands for a need to pay for numerous medical services (in particular if a patent does not want to wait a long time in a queue for a specialist). On the other hand, such commercialisation is connected with numerous services being subcontracted out by the national health fund (NFZ) to private medical units. Low expenditures in the scope of health care and leaks of state funds to private companies engaged in the provision of health services must result in hindered and unequal access to health care. Based on Ladislau Dowbor data, Norway spends $9,6 \%$ of GDP for health care, including $8 \%$ in the public sector and 1,6\% - in the private sector; Canada also spends $9,6 \%$ of GDP, including $6,7 \%$ in the public sector and $2,9 \%$ in the private sector, and the United States - 14,6\% of GDP, of which $6,6 \%$ - in the public sector and $8 \%$ in the private sector ${ }^{10}$. Poland does only about $7 \%$ of GDP. In 2013, Norway was ranked 1st in terms of the Human Development Index, Canada and the United States were in the top ten and Poland was ranked 39th. The heath service sector analysts predict that the private market of health services will expand in Poland. Therefore, $82 \%$ of respondents' declarations that high-income people are better treated in hospitals should not be surprising at all.

\footnotetext{
${ }^{9}$ G. W. Kołodko, Świat na wyciagnięcie myśli, Warsaw 2010, pp. 94-95.

${ }^{10}$ L. Dowbor, Demokracja ekonomiczna, Book and Press, Warsaw 2009, p. 118.
} 
Table 3 .

In your opinion, which groups of people - due to their income - are better treated: in Polish hospitals?

\begin{tabular}{lcccc}
\hline & $\begin{array}{c}\text { high-income } \\
\text { people }\end{array}$ & $\begin{array}{c}\text { middle-income } \\
\text { people }\end{array}$ & $\begin{array}{c}\text { low-income } \\
\text { people }\end{array}$ & $\begin{array}{c}\text { it doesn't } \\
\text { matter }\end{array}$ \\
\hline Total & 82,1 & 6,2 & 1,0 & 11,1 \\
\hline Men & & Sex & & \\
\hline Women & 80,8 & 6,8 & 0,8 & 11,6 \\
\hline $18-24$ & 83,3 & 5,7 & 0,4 & 10,6 \\
\hline $25-34$ & & Age & & \\
\hline $35-44$ & 75,9 & 13,9 & 0,9 & 9,3 \\
\hline $45-54$ & 87,1 & 4,0 & 1,0 & 10,6 \\
\hline $55-64$ & 81,8 & 7,1 & 0,6 & 9,0 \\
\hline 65 and over & 87,2 & 3,2 & 0,6 & 8,9 \\
\hline
\end{tabular}

Source: Centrum Monitoringu Społecznego

Table 4 .

In your opinion, which groups of people - due to their income - are better treated: in banks?

\begin{tabular}{lcccc}
\hline & $\begin{array}{c}\text { high-income } \\
\text { people }\end{array}$ & $\begin{array}{c}\text { middle-income } \\
\text { people }\end{array}$ & $\begin{array}{c}\text { low-income } \\
\text { people }\end{array}$ & $\begin{array}{c}\text { it doesn't } \\
\text { matter }\end{array}$ \\
\hline Total & 72,4 & 11,6 & 0,8 & 15,2 \\
\hline Men & & Sex & & \\
\hline Women & 74,5 & 11,8 & 1,1 & 12,7 \\
\hline $18-24$ & 70,6 & 11,4 & 0,6 & 17,5 \\
\hline $25-34$ & & Age & & \\
\hline $35-44$ & 66,7 & 19,4 & 1,9 & 12,0 \\
\hline $45-54$ & 80,1 & 12,4 & 0,5 & 7,0 \\
\hline $55-64$ & 76,0 & 8,8 & 0,6 & 14,6 \\
\hline 65 and over & 78,2 & 9,6 & 0,6 & 11,5 \\
\hline
\end{tabular}

Source: Centrum Monitoringu Społecznego 
The banking sector is assessed similarly; it is geared primarily for giving credits to people who need them least. People with no contract of employment have no opportunity to receive a bank loan. Moreover, $72 \%$ of the respondents consider that banks treat high-income people better than poor people.

In general, when a social welfare state declines, its place is taken by a penal or police state. According to Bauman,

in the world of global finances, the role of national governments comes down only to playing the role of a somewhat more complex police station. A number of police officers per district and quality of their training; 'clearing' beggars, intruders and petty thieves off streets, thickness of prison walls - these are the factors which have a major impact on 'investors' confidence' and they are taken under consideration when making a decision on undertaking or withdrawal from investments ${ }^{11}$.

In this way the state - resigning from its social functions - seeks to create a welcoming space for entrepreneurs and capital-owners. For this reason tools of repression are assumed to be directed not against business circles or higher-class people but against lower-class representatives. As Loïc Wacquant demonstrates,

\begin{abstract}
American prisons are not populated by dangerous and unrepentant criminals but by petite rogues sentenced for drugs, burglary, theft and disorder. They usually come from poorer segments of the working class, in particular from families of the coloured under-proletariat affected by changes in the labour market and declining welfare. (...) In county prison cells, 6 out of 10 residents were Afro Americans or Latin Americans; less than half of them worked full time when sentenced. Two thirds came from facilities with their incomes not exceeding half of the poverty threshold ${ }^{12}$.
\end{abstract}

In Polish conditions, omitting racial aspects, the population of prisons is similar - a vast majority of sentenced people come from lower classes.

The phenomenon of poverty penalisation very clearly shows class determinants of the social process of "crime production". It all starts at the stage of establishing criminal regulations. As Zygmunt Bauman rightly points out:

Acts are mostly committed by people for whom there is no space in a settled order, by socially disadvantaged and oppressed people; they have got the largest chance to violate the criminal code. Robbing whole nations of their wealth is called 'promotion of free market'; robbing families and local communities of their means is called 'reduc-

11 Z. Bauman, op. cit., p.141

${ }^{12}$ L. Wacquant, Więzienia nędzy, Book and Press, Warsaw 2009, pp. 82-83. 
tion in employment' or just 'modernisation'. None of these acts has been called a criminal offence, and none of them has been subject to punishment ${ }^{13}$.

Police interventions are at the next stage in the process of "crime production". In order to achieve good results in detection and to improve police statistics, officers usually undertake their "hunting" for potential offenders in the worst (poorer) urban districts. Young people from lower social classes are easier to apprehend with possession of a small amount of drugs than higher-class people committing more sophisticated crimes; this is surely understood by "every police unit dedicated to fighting serious crimes. Illegal acts committed "at the top" are extremely difficult to catch as they are woven into a dense network of "common" business affairs. When it comes to actions clearly aimed to achieve benefits at the cost of others, the boundary between lawful and unlawful acts is poorly defined and always remains debatable"14. In addition, people from middle and higher classes can afford a good lawyer and professional assistance at court as opposed to people from lower classes. In Poland only a small proportion of people called to court make use of professional attorney assistance.

So the respondents' opinions on the administration of justice and the repression apparatus should not be surprising. More than $56 \%$ of the respondents state that high-income people are better treated by the police and only $27,6 \%$ of them declare that their class origin is irrelevant during police interventions. Even more - nearly $70 \%$ of the respondents - consider that high-income people have more chances to win in court. And only $27,9 \%$ are of opinion that court judgments are not affected by their class position.

There are similar proportions in the case of their opinions on the social origin of people imprisoned in Poland. According to a majority of the residents (54,6\%), "people from lower social classes reside there" and 37\% claim that people from various social groups stay there. And, although in order to establish the detailed profile of people imprisoned in Poland it is necessary to run separate sociological studies, it seems that social feelings do not deviate too far from reality.

Trying to outline the impact of psycho-social features on judgments of Polish courts, Tomasz Kaczmarek advocates that penalties administered by judges in courts are relevantly impacted by the following factors: a lev-

13 Z. Bauman, op. cit., p. 145.

14 Ibidem, p.145. 
Table 5.

\begin{tabular}{lcccc}
\hline \multicolumn{4}{c}{ In your opinion, which groups of people - due to their income - are better treated: } \\
by police in Poland? \\
$\begin{array}{l}\text { high-income } \\
\text { people }\end{array}$ & $\begin{array}{c}\text { middle-income } \\
\text { people }\end{array}$ & $\begin{array}{c}\text { low-income } \\
\text { people }\end{array}$ & $\begin{array}{c}\text { it doesn't } \\
\text { matter }\end{array}$ \\
\hline Total & 56,4 & 14,5 & 1,5 & 27,6 \\
\hline Men & 59,0 & Sex & & \\
\hline Women & 13,7 & 1,1 & 26,2 \\
\hline & 54,1 & 15,2 & 1,9 & 28,8 \\
\hline $18-24$ & 59,3 & Age & & 22,2 \\
\hline $25-34$ & 58,4 & 14,8 & 3,7 & 32,2 \\
\hline $35-44$ & 50,9 & 16,3 & 1,0 & 23,1 \\
\hline $45-54$ & 63,5 & 14,0 & 2,9 & 26,8 \\
\hline $55-64$ & 58,4 & 12,8 & 0,6 & 35,6 \\
\hline 65 and over & 48,3 & 13,7 & 1,1 & \\
\hline
\end{tabular}

Source: Centrum Monitoringu Społecznego

Table 6.

Who has a better chance of winning in court?

\begin{tabular}{|c|c|c|c|c|}
\hline & $\begin{array}{l}\text { high-income } \\
\text { people }\end{array}$ & $\begin{array}{l}\text { middle-income } \\
\text { people }\end{array}$ & $\begin{array}{l}\text { low-income } \\
\text { people }\end{array}$ & $\begin{array}{l}\text { it doesn't } \\
\text { matter }\end{array}$ \\
\hline & \multicolumn{4}{|c|}{$[\%]$} \\
\hline Total & 69,6 & 2,1 & 0,4 & 27,9 \\
\hline \multicolumn{5}{|c|}{ Sex } \\
\hline Men & 73,6 & 2,1 & 0,6 & 23,7 \\
\hline Women & 66,0 & 2,1 & 0,2 & 31,7 \\
\hline \multicolumn{5}{|c|}{ Age } \\
\hline $18-24$ & 50,9 & 3,7 & 0,0 & 45,4 \\
\hline $25-34$ & 64,2 & 1,0 & 0,0 & 34,8 \\
\hline $35-44$ & 68,4 & 4,1 & 0,6 & 26,9 \\
\hline $45-54$ & 80,0 & 1,3 & 0,6 & 18,1 \\
\hline $55-64$ & 74,3 & 1,6 & 0,5 & 23,6 \\
\hline 65 and over & 74,1 & 1,7 & 0,6 & 23,6 \\
\hline
\end{tabular}

Source: Centrum Monitoringu Społecznego 
Table 7.

In your opinion, from which social groups do the largest number of people in Polish prisons come from?

\begin{tabular}{lcccc}
\hline & $\begin{array}{c}\text { people from } \\
\text { various so- } \\
\text { cial groups are } \\
\text { there }\end{array}$ & $\begin{array}{c}\text { mostly people } \\
\text { from lower so- } \\
\text { cial classes are } \\
\text { there }\end{array}$ & $\begin{array}{c}\text { mostly high-in- } \\
\text { come people } \\
\text { who wanted } \\
\text { to get enriched } \\
\text { unfairly are } \\
\text { there }\end{array}$ & $\begin{array}{c}\text { it difficult to } \\
\text { say }\end{array}$ \\
\hline Total & 37,0 & 54,6 & 4,9 & 3,5 \\
\hline Men & 32,8 & Sex & & \\
\hline Women & 40,8 & 57,3 & 5,5 & 2,4 \\
\hline $18-24$ & 52,2 & 4,4 & 0,9 \\
\hline $25-34$ & 42,6 & Age & & 1,5 \\
\hline $35-44$ & 34,2 & 50,9 & 5,6 & 2,3 \\
\hline $45-54$ & 42,1 & 59,4 & 3,5 & 4,5 \\
\hline $55-64$ & 37,4 & 52,0 & 3,9 & 6,7 \\
\hline 65 and over & 33,0 & 54,2 & 3,7 & 6,9 \\
\hline
\end{tabular}

Source: Centrum Monitoringu Społecznego

el of their neuroticism, opportunism / non-conformism, dominance / submissiveness towards pressures of specific social groups or a degree of satisfaction / dissatisfaction with their occupation"15. It would be interesting to determine the impact of class variances and social distances separating judges and sentenced people onto court judgments.

\section{ANTI-EGALITARIAN CURRENTLY AND PATTERNS FOR POLAND}

The respondents - when they were asked when (in their opinion) the largest social disparities have taken place - pointed to the present times. Only $8,3 \%$ of the respondents pointed to the period before 1989 as the time

15 T. Kaczmarek, Wptyw osobowości sędziego na wymiar kary, in Kulturowe uwarunkowania polityki kryminalnej, ed. by Marian Filar, Jarosław Utrat-Milecki, Warsaw 2014, p. 207 
Table 8 .

In your opinion, from which social groups do the largest number of people in Polish In your opinion when have the largest inequalities taken place:

\begin{tabular}{|c|c|c|c|c|}
\hline & Before 1989 & $\begin{array}{l}\text { In 90s of } 20 \text { th } \\
\text { century }\end{array}$ & Nowadays & $\begin{array}{c}\text { It is difficult } \\
\text { to say }\end{array}$ \\
\hline & \multicolumn{4}{|c|}{ [\%] } \\
\hline Total & 8,3 & 6,5 & 81,1 & 4,1 \\
\hline \multicolumn{5}{|c|}{ Sex } \\
\hline Men & 9,3 & 7,6 & 79,7 & 3,4 \\
\hline Women & 7,4 & 5,5 & 82,4 & 4,7 \\
\hline \multicolumn{5}{|c|}{ Age } \\
\hline $18-24$ & 9,3 & 13,9 & 69,4 & 7,4 \\
\hline $25-34$ & 5,0 & 9,0 & 82,6 & 3,5 \\
\hline $35-44$ & 7,1 & 9,4 & 78,2 & 5,3 \\
\hline $45-54$ & 8,9 & 3,2 & 84,1 & 3,8 \\
\hline $55-64$ & 9,4 & 4,2 & 82,7 & 3,7 \\
\hline 65 and over & 10,3 & 2,3 & 84,5 & 2,9 \\
\hline \multicolumn{5}{|c|}{ Political opinions } \\
\hline Left-wing & 10,0 & 5,0 & 82,0 & 3,0 \\
\hline Rather left-wing & 5,9 & 5,9 & 86,1 & 2,0 \\
\hline Central-wing & 6,6 & 10,2 & 79,6 & 3,6 \\
\hline Rather right-wing & 12,1 & 7,8 & 77,6 & 2,6 \\
\hline Right-wing & 7,7 & 7,7 & 82,4 & 2,1 \\
\hline \multicolumn{5}{|c|}{ Professional standing } \\
\hline Public sector staff & 9,4 & 6,7 & 80,8 & 3,1 \\
\hline Private sector staff & 7,7 & 8,9 & 78,3 & 5,1 \\
\hline Private entrepreneurs & 2,3 & 7,0 & 86,0 & 4,7 \\
\hline Farmers & 12,5 & 6,2 & 81,2 & 0,0 \\
\hline Disability pensioners & 13,8 & 13,8 & 65,5 & 6,9 \\
\hline Old-age pensioners & 9,3 & 1,6 & 84,6 & 4,5 \\
\hline Pupils and students & 6,7 & 11,1 & 80,0 & 2,2 \\
\hline Unemployed persons & 2,4 & 14,3 & 78,6 & 4,8 \\
\hline $\begin{array}{l}\text { Other economically } \\
\text { inactive }\end{array}$ & 10,3 & 0,0 & 87,2 & 2,6 \\
\hline
\end{tabular}


of the worst inequalities. Interestingly, this group included the largest number of the young people $(9,3 \%)$ and the oldest ones $(10,3 \%)$. Besides these groups, both farmers $(12,5 \%)$ and disability pensioners $(13,8 \%)$ pointed out that the period of the PRL (Communist) times was more non-socially aware. A small group of the respondents $(6,5 \%)$ selected the 90 s (at the beginning of the Polish transformation) as the period of the largest social disparities.

The manner people assess their own position depends - as it is well known - on those with whom they are compared. The point of reference not only affects their assessment of the compared sphere of life but also provides social patterns, values and inspirations for the subject of comparison. As Marek Ziółkowski wrote, the Polish system transformation was imitative in its character - thus we may say about "imitative modernisation". What was being imitated? Obviously, a more or less simplified and idealised image of the "West". However, as noted by Ziółkowski, "there are obvious differences between particular modern societies, for example between more 'social-democratic' Swedish capitalism and more 'liberal' American capitalism". And the order which we have imitated. "Namely, institutions, patterns of behaviour and values belonging at least to several developmental phases of societies of advanced capitalism objectively affect us; they are unconsciously implemented or deliberately introduced into life"16. In Polish conditions, inspirations were drawn from various phases of capitalism - both from its nineteenth-century versions in which the world of work was not protected by any social rights and from the period of "late capitalism" in which consumption replaces production as a propelling motor of economies. However, a statement can be ventured that particularly the first decade of restoration of capitalism in Poland was subjected to neo-liberal principles organising social and economical affairs of the new political order. In this manner - as noted by Tadeusz Kowalik - "a paradoxical situation was created: we have stubbornly been heading for Western Europe but via Washington and London (...). For example in health care and pension reforms, and even education, we have "marketised" much more than Western Europe has done, not to mention a range of approved foreign capital, especially in banking"17. In

${ }^{16}$ M. Ziółkowski, O różnorodności teraźniejszości. Pomiędzy tradycją, spuścizną socjalizmu, nowoczesnością i ponowoczesnością, [in:] A. Sułek, M.S. Szczepański (Ed.), Ślask-Polska-Europa. Zmieniajace się społeczeństwo w perspektywie lokalnej i globalnej, Katowice 1998, pp. 88-89.

17 T. Kowalik, Społeczna gospodarka rynkowa - konstytucyjnym wyzwaniem dla Polski, [in:] Człowiek, rynek, sprawiedliwość, Warszawa 2001, p.117 
other words, patterns for the new order in Poland after 1989 have come more from American capitalism rather than from its more human version in Germany or Scandinavia. And how - 25 years after the system change is a range of inequalities in Poland assessed when compared with other selected countries? Scandinavian countries (Sweden and Norway) together with Germany and France (representing "Rhine capitalism" with a large share of the state in their economies) are assessed most favourably by the public. It is also interesting that the Czech Republic, a direct neighbour of Poland, which has also undergone transformational processes, is treated as a country with lower inequities (it is considered so by $41 \%$ of the respondents) compared with Poland. The countries which the respondents classified to the ones with higher inequities compared with Poland are as follows: the United States (more non-socially-aware as expressed by $54 \%$ of the respondents), Romania (59\%), Egypt (69\%) and Russia (80\%).

Then, the countries which should - as expressed by the respondents be the model for Poland are as follows (by order): Norway $(76 \%)$, Sweden (76\%), Germany (72\%), France (58\%), and Czech Republic (43\%). Countries in the lower range are as follows: the United States, Russia, Romania and Egypt. There was a closed list of countries provided to the respondents in these two questions. Had the list been longer, their results would surely differ in some details, but the obtained results show a trend in the assessment of the existing social orders by the Polish society. As claimed by Tadeusz Kowalik, the basic question is as follows: "Will Poland dare and will the authorities be strong enough to get off of the disastrous road of unbridled capitalism and to start building a system based on German, Austrian or Swedish experience. The last half-century has brought considerable system differentiation in the capitalistic world as well. (...) Even nowadays within the European Union, it is easy to notice a large range of differentiation"18. And although these words were written before the crisis which erupted globally in 2008 and brought some restrictions in the spirit of neo-liberalism to Europe, there have been still considerable differences between socio-economic philosophies implemented in particular countries. In Poland, however, the invisible hand of the market is believed to bring order with no social or state supervision.

This "market religion" also manifests itself in the everyday life of the Polish society which is dominated by individualistic problem-solving strategies (which usually have the most collective and systemic na-

${ }^{18}$ Ibidem, pp. 150-151. 
Chart 3. Comparison of the level of social inequalities in Poland and selected countries. $\mathrm{N}=1000$

\section{Comparison of social inequities}

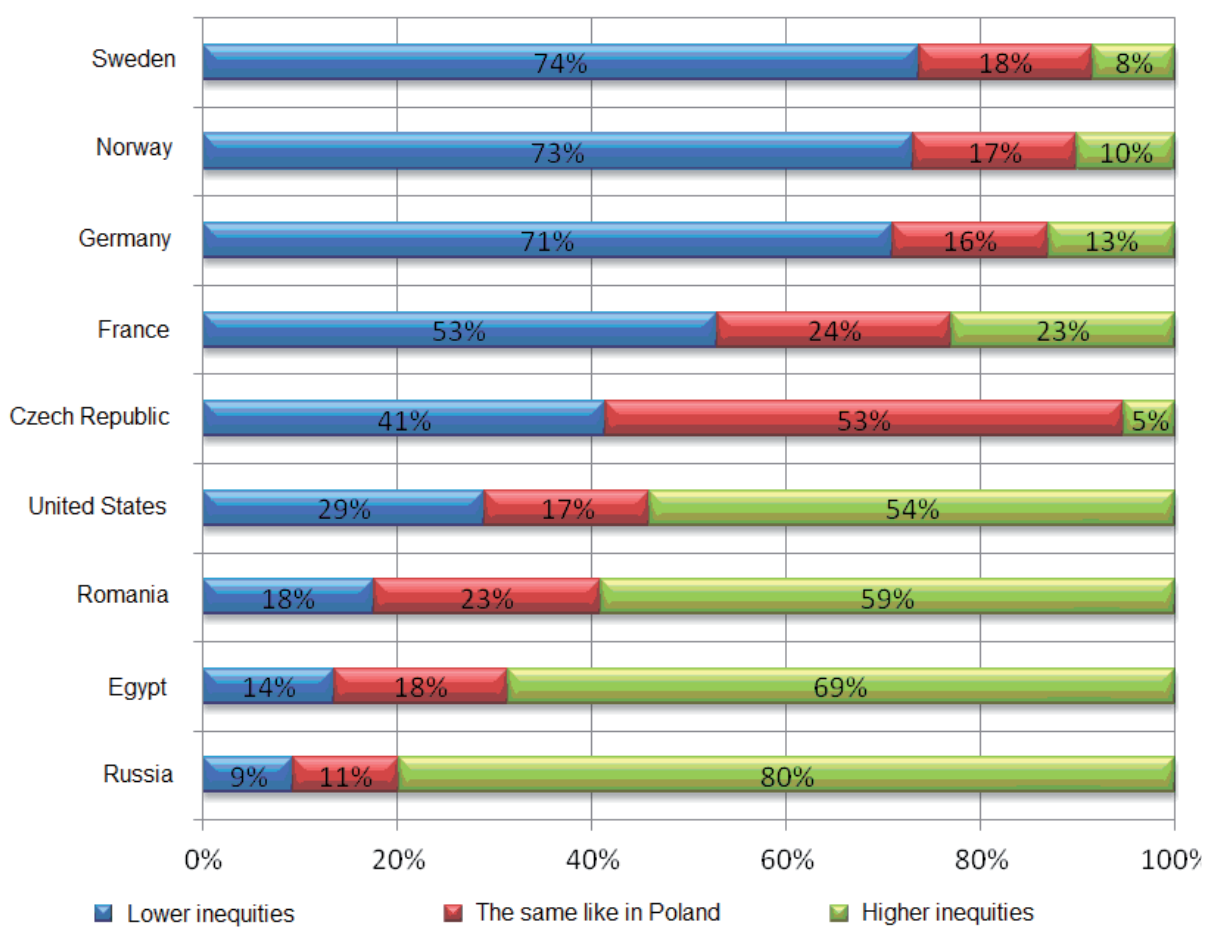

Source: Centrum Monitoringu Społecznego

ture). Group and collective actions are not fashionable and also stem from a widespread belief that only business "on your own" can lead to success. It is also often accompanied by the belief that inequality is a "natural state". As emphasised by the authors of "The Spirit Level", "it has been often heard that greater equality is impossible as people are not equal. This argument is based on the following misunderstanding: equal does not mean "the same". People did not become the same when the principle of equality before the law was adopted"19.

In the presented studies - as shown in Table 9 - nearly $11 \%$ of the respondents said that "people by nature are unequal - some occupy higher positions and others lower ones". It is interesting that age turned out to be a factor which has heavily influenced the variation in acceptance of this

${ }^{19}$ R. Wilkinson, K. Pickett, Duch równości, Warszawa 2011, p.250. 
Chart 4. Countries which should be a model for Poland in the scope of social stratification. $\mathrm{N}=1000$

\section{Model for Poland in the scope of social differentiation}

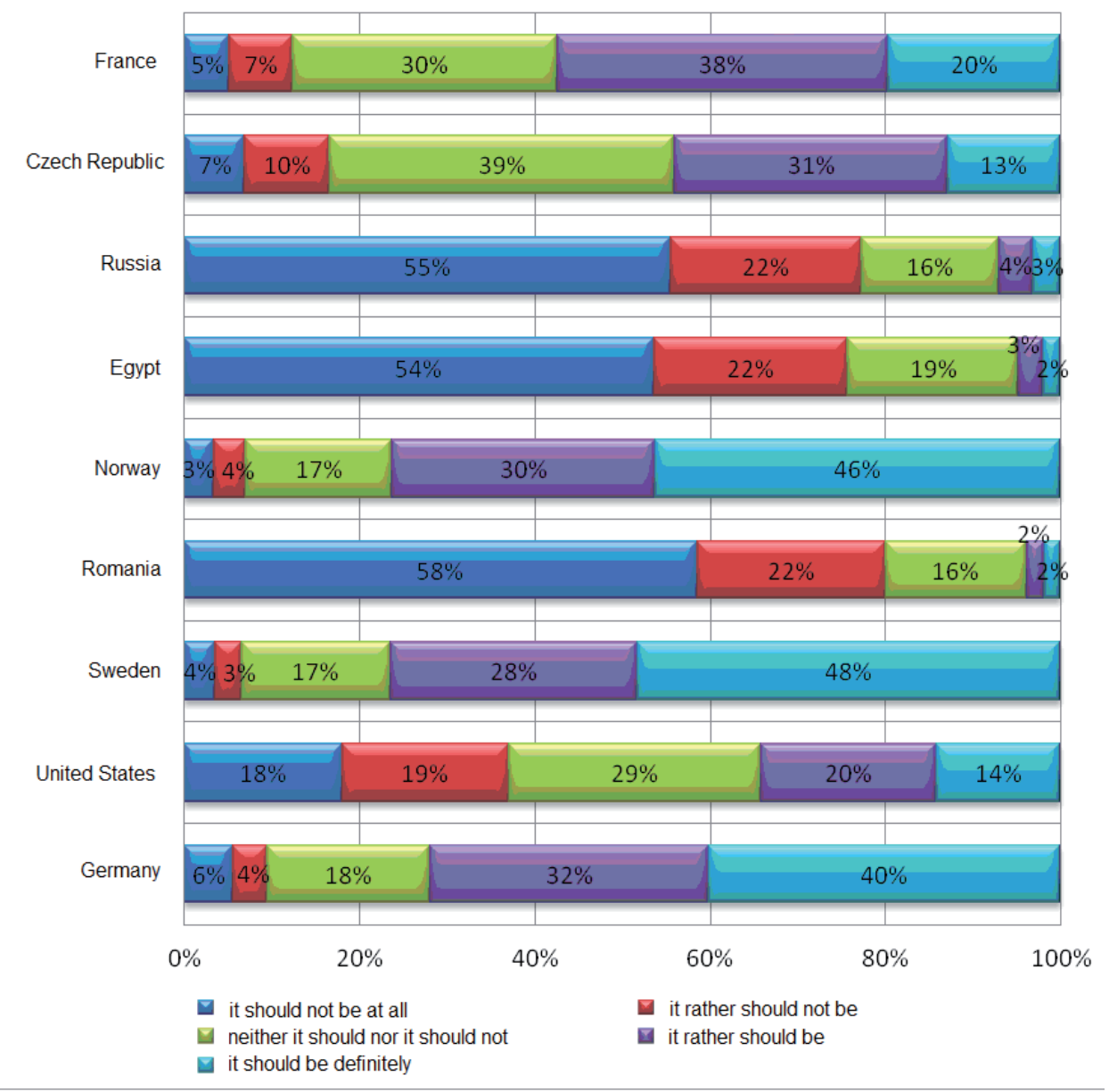

Source: Centrum Monitoringu Społecznego

view - the older the people were, the less they accepted views on "natural inequalities". About $23 \%$ of the residents agree with the statement that "more hard-working people reach higher positions and earn more, and less diligent ones earn less". Such opinion seeks to explain social inequities through attitudes of individuals themselves with some of them being "hard-working" and others, "lazy". This is a kind of attempt to "psychol- 


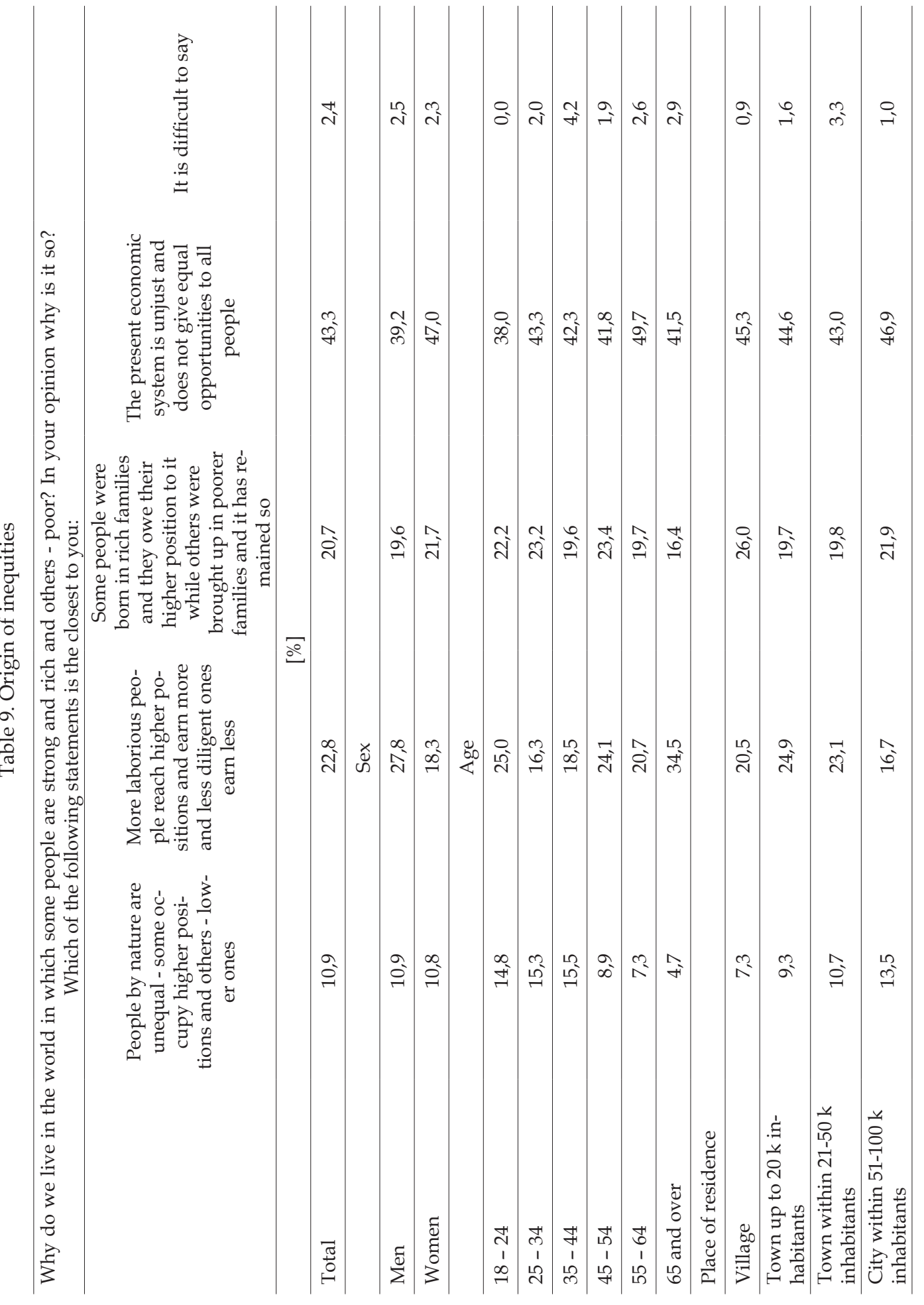




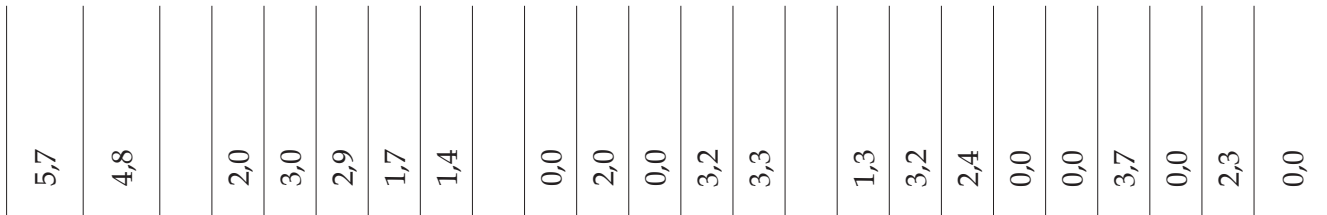

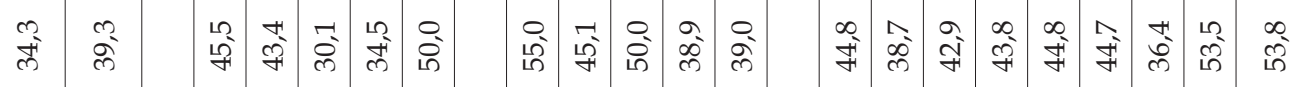

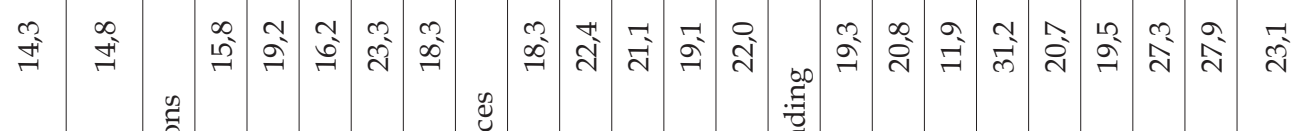

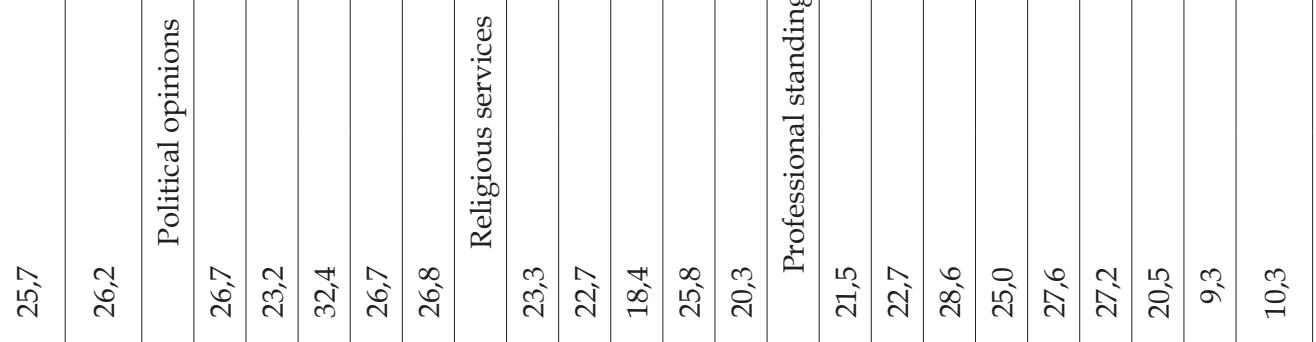

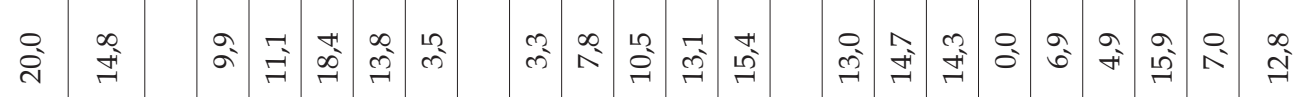

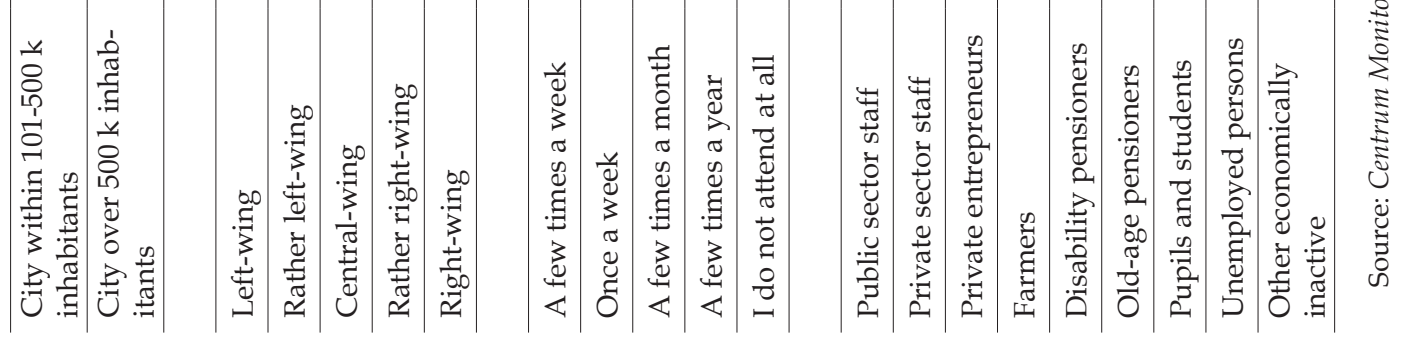


ogise" the phenomenon which is mostly systematic in character and related to one or another social model.

Nearly $21 \%$ of the residents point to the succession of social status nowadays - people who are born in poor families remain poor in subsequent generations. However, up to $43,3 \%$ of the respondents approved the statement that "the present economic system is unjust and does not give equal opportunities to all people". Significant differences in the expression of this opinion referred to sex $-47 \%$ of the female respondents thought so and $39 \%$ of the male respondents did.

And although Richard Wilkinson and Kate Picket are convinced of constant progress and extension of egalitarian relationships, a lot of people in Poland consider that the system they live in is unfair, according to the results of this study. Wilkinson and Picket defend the thesis of growing egalitarianism in the modern world illustrating it through regulations which protect the rights of workers and tenants, abolition of the death penalty and corporal punishments or growing agitation "in favour of equal opportunities - regardless of race, class, sex, sexual orientation and religion" ${ }^{20}$. It is easy to notice these slogans at the present time, but trends in the most relevant area of inequalities which is the sphere of socio-economic relationships are completely different; the differences between the rich and poor do not decrease, but increase in global terms. The changes of the last 25 years in the Polish society are a good example of these processes.

Piotr Żuk - PhD, Professor at University of Wrocław, Head of Department of Sociology of the Public Sphere. Author, co-author and editor of several books. Recently published: Podziaty klasowe i nierówności społeczne [Class divisions and social inequities, Warszawa 2010], Wiedza, ideologia, władza. O społecznej funkcji uniwersytetu w społeczeństwie rynkowym [Knowledge, ideology, power. The social function of university in a market society, Warszawa 2012], Wspótczesne oblicza autorytaryzmu [Contemporary faces of authoritarianism, Warszawa 2014]. Columnist of "Przegląd" Weekly. Combines academic work with public activity for the democratization of society and the protection of civil rights.

${ }^{20}$ R. Wilkinson, K. Pickett, op. cit., pp. 279-280. 